\title{
Gambaran indeks Maya pada rumah penderita demam berdarah dengue di Kelurahan Kombos Barat Kecamatan Singkil tahun 2015
}

\author{
${ }^{1}$ Ivan T. Sigarlaki \\ ${ }^{2}$ Victor D. Pijoh \\ ${ }^{2}$ Josef S. B. Tuda
}

\author{
${ }^{1}$ Kandidat Skripsi Fakultas Kedokteran Universitas Sam Ratulangi Manado \\ ${ }^{2}$ Bagian Parasitologi Fakultas Kedokteran Universitas Sam Ratulangi Manado \\ Email: ivansigarlaki@gmail.com
}

\begin{abstract}
Dengue hemorrhagic fever (DHF) is a viral disease that can cause death within a very short time (a few days). The main vector of DHF is Aedes aegypti mosquito, whereas the potential vector is Aedes albopictus. In the context of prevention of DHF, environmental data associated with bionomics mosquito vector of DHF, the Maya Index, are needed. DHF is still a public health problem. And for the case that there is in the city of Manado in 2013, in this case in the district of Singkil, acquired as many as 43 cases of dengue hemorrhagic fever. This study aimed to describe the Maya Index at the houses of dengue hemorrhagic fever patients in the village of West Kombos, Singkil districts. Maya Index is based on hygiene risk index (HRI) and breeding risk index (BRI). This was a descriptive study. Samples were houses of patients with DHF in 2015 from January to December. The results showed that there were four patients during the year 2015. Observation of the four houses and calculation of the data indicated that two houses were in low category of Maya Index, one house in medium category of Maya Index, and one house in high category of Maya Index.
\end{abstract}

Keywords: dengue hemorrhagic fever, Maya index

\begin{abstract}
Abstrak: Demam berdarah dengue (DBD) adalah penyakit virus yang berbahaya karena dapat menyebabkan kematian dalam waktu yang sangat singkat (beberapa hari). Vektor utama DBD ialah nyamuk Aedes aegypti, sedangkan vektor potensialnya ialah Aedes albopictus. Dalam konteks penanggulangan DBD, juga diperlukan data lingkungan terkait dengan segi bionomik nyamuk vektor DBD, yaitu Indeks Maya. DBD masih merupakan masalah kesehatan masyarakat di kota Manado. Pada tahun 2013, di Kecamatan Singkil didapatkan sebanyak 43 kasus DBD. Penelitian ini bertujuan untuk mengetahui gambaran Indeks Maya pada rumah penderita DBD di Kelurahan Kombos Barat Kecamatan Singkil. Indeks Maya didasarkan pada hygiene risk index (HRI) dan breeding risk index (BRI). Jenis penelitian ialah deskriptif. Sampel penelitian ialah rumah dari penderita DBD tahun 2015 sejak bulan Januari-Desember. Dari hasil penelitian didapatkan empat penderita sepanjang tahun 2015 dan setelah dilakukan observasi ke rumah penderita dan perhitungan data didapatkan dua rumah masuk pada kategori Indeks Maya rendah, satu rumah masuk pada kategori Indeks Maya sedang, dan satu rumah masuk kategori Indeks Maya tinggi.
\end{abstract}

Kata kunci: demam berdarah dengue, indeks Maya

Demam berdarah dengue (DBD) merupakan penyakit akibat virus yang berbahaya karena dapat menyebabkan kematian dalam waktu yang sangat singkat (beberapa hari). Penyakit ini masuk ke
Indonesia tahun 1968 melalui pelabuhan Surabaya dan pada tahun 1980 telah dilaporkan tersebar luas di seluruh provinsi di Indonesia. ${ }^{1}$ Vektor utama DBD ialah nyamuk rumah Aedes aegypti, sedangkan 
vektor potensialnya yang lain ialah Aedes albopictus yang banyak ditemukan di semak-semak sekitar rumah. ${ }^{2}$

DBD masih merupakan masalah kesehatan masyarakat. Berdasarkan Data dan Informasi Kementerian Kesehatan Indonesia tahun 2014, persentase jumlah kabupaten/kota tahun 2014 terjadi peningkatan sebesar 84,74/497 kabupaten/kota. ${ }^{3}$

Untuk kasus yang terdapat di Kota Manado pada tahun 2013, dalam hal ini di Kecamatan Singkil, didapat sebanyak 43 kasus DBD. ${ }^{4}$ Dan pada bulan Oktober tahun 2015 terdapat kasus baru DBD. ${ }^{5}$

Kecamatan Singkil adalah salah satu dari 11 kecamatan yang ada di Manado. Letaknya berbatasan langsung dengan Kecamatan Tuminting sebelah utara, sebelah selatan berbatasan dengan DAS Tondano, Kecamatan Wenang, sebelah timur berbatasan dengan Kecamatan Tikala. Luas wilayah Kecamatan Singkil sebesar 3,86 $\mathrm{km}^{2}$ atau 2,45 persen dari total luas daratan Kota Manado. Topografi Kecamatan Singkil adalah daratan dan perbukitan. Rata-rata wilayah Kecamatan Singkil jarak dari kecamatan ke kelurahan bervariasi. Kombos Timur berada pada jarak terjauh $3 \mathrm{~km}$ dengan waktu tempuh 15 menit dan yang terdekat Kelurahan Singkil Satu dengan waktu tempuh lima menit. Kecamatan Singkil terdiri dari 9 kelurahan yaitu Kelurahan Karame, Kelurahan Ketang Baru, Kelurahan Wawonasa, Kelurahan Ternate Baru, Kelurahan Ternate Tanjung, Kelurahan Kombos Barat, Kelurahan Kombos Timur, Kelurahan Singkil Satu, dan Kelurahan Singkil Dua, setiap kelurahan dibagi menjadi beberapa lingkungan. ${ }^{6}$

Jumlah penduduk Kecamatan Singkil pada tahun 2014 sebesar 47.693 jiwa. Dengan luas wilayah $3,86 \mathrm{~km}^{2}$, maka kepadatan penduduk setiap kilometer persegi Kecamatan Singkil ialah 12.425 jiwa. Jumlah penduduk laki-laki di Kecamatan Singkil lebih banyak dari penduduk perempuan. Dari segi pendidikan, di Kecamatan Singkil sudah tercatat tamatan-tamatan sekolah hingga perguruan tinggi. Tamatan SD tercatat 24,33\% dari jumlah penduduk, SLTP 21,11\%, SMU 47,03\%, S1 7,17\% dan S2 ke atas $0,37 \%{ }^{6}$

Dalam konteks penanggulangan DBD, juga diperlukan data lingkungan terkait dengan segi bionomik nyamuk vektor DBD, yaitu Maya Index/Indeks Maya. Bionomik merupakan hubungan antara aktivitas dan perilaku nyamuk dalam kesehariannya dengan lingkungan. Indeks Maya digunakan dalam upaya pengendalian DBD di suatu daerah. Dengan Indeks Maya, bisa diketahui tingkat risiko perkembangbiakan jentik yang berguna untuk menentukan prioritas dalam penyusunan program pengendalian larva. Selain itu, dapat diketahui tempat perkembangbiakan yang paling disukai sebagai acuan dalam program pengendalian larva nyamuk. ${ }^{7}$ Penelitian yang berkaitan dengan Indeks Maya telah dilakukan di beberapa tempat, salah satunya di Kota Banjar. Pada penelitian yang dilakukan di Kota Banjar pada tahun 2012 diperiksa 100 rumah yang dipilih berdasarkan adanya anggota keluarga yang pernah menderita penyakit DBD pada tahun 2010 dan tercatat di Dinas Kesehatan Kota Banjar. Dan dari hasil penelitian tersebut didapat satu rumah yang masuk dalam kategori Indeks Maya rendah, 97 rumah masuk kategori sedang, dan dua rumah masuk dalam kategori tinggi. $^{8}$

Penelitian ini bertujuan untuk mengetahui gambaran Indeks Maya pada rumah penderita demam berdarah dengue di Kelurahan Kombos Barat Kecamatan Singkil.

\section{METODE PENELITIAN}

Jenis penelitian ini ialah deskriptif. Penelitian ini dilaksanakan di pemukiman masyarakat Kelurahan Kombos Barat Kecamatan Singkil pada bulan Oktober sampai Desember tahun 2015. Pengambilan data sekunder berupa data penderita DBD di Puskesmas Kombos Timur. Wilayah Kombos Barat ialah salah satu wilayah kerja dari Puskesmas Kombos Timur. Pengambilan sampel menggunakan cara 
purposive sampling yaitu rumah penduduk yang pernah menderita DBD pada bulan Januari-Desember 2015 di Kelurahan Kombos Barat Kecamatan Singkil yang telah didokumentasikan oleh Puskesmas Kombos Timur.

Definisi operasional dari Indeks Maya adalah hasil perhitungan Hygiene Risk Index (HRI) dan Breeding Risk Index (BRI) berdasarkan data-data yang didapat di tiap rumah penduduk Kelurahan Kombos Barat Kecamatan Singkil kemudian dimasukkan dalam matriks 3x3 untuk mendapat kategori Indeks Maya, dan untuk definisi operasional dari DBD ialah masyarakat di Kelurahan Kombos Barat Kecamatan Singkil yang pernah menderita penyakit
DBD pada bulan Januari-Desember 2015. Data penderita diambil di Puskesmas Kombos Timur.

\section{HASIL PENELITIAN}

Berdasarkan data dari Puskesmas Kombos Timur terdapat total empat penderita demam berdarah pada tahun 2015, yaitu pada bulan Januari terdapat satu penderita, bulan Juli dua penderita, dan bulan Oktober satu penderita. Kunjungan dilakukan ke rumah-rumah penderita tersebut, dan dilakukan observasi. Perhitungan data berdasarkan controllable container dan disposable container kemudian ditabulasi.

Tabel 1. Hasil perhitungan BRI tiap rumah.

\begin{tabular}{ccccc}
\hline Rumah & Jumlah CC & $\begin{array}{c}\text { CC positif } \\
\text { Larva }\end{array}$ & $\begin{array}{c}\text { Rerata CC } \\
\text { positif }\end{array}$ & BRI \\
\hline 1 & 17 & 1 & 0,05 & 340 \\
2 & 23 & 2 & 0,08 & 287,5 \\
3 & 7 & 3 & 0,42 & 16,66 \\
4 & 9 & 1 & 0,11 & 81,81 \\
Total & 56 & 7 & & \\
\hline
\end{tabular}

Tabel 2. Hasil perhitungan HRI tiap rumah.

\begin{tabular}{ccccc}
\hline Rumah & Jumlah DC & $\begin{array}{c}\text { DC positif } \\
\text { larva }\end{array}$ & $\begin{array}{c}\text { Rata-rata DC } \\
\text { positif }\end{array}$ & HRI \\
\hline 1 & 9 & 1 & 0,11 & 81,81 \\
2 & 6 & 2 & 0,33 & 18,18 \\
3 & 7 & 1 & 0,14 & 50 \\
4 & 8 & 1 & 0,125 & 64 \\
Total & 30 & 5 & & \\
\hline
\end{tabular}

Tabel 3. Pengelompokkan rumah ke dalam kategori BRI, HRI, dan Indeks Maya.

\begin{tabular}{cccc}
\hline Rumah & Kategori BRI & $\begin{array}{c}\text { Kategori } \\
\text { HRI }\end{array}$ & Indeks Maya \\
\hline 1 & Tinggi & Tinggi & Tinggi \\
2 & Sedang & Rendah & Rendah \\
3 & Rendah & Sedang & Rendah \\
4 & Sedang & Sedang & Sedang \\
\hline
\end{tabular}

\section{BAHASAN}

Dari hasil penelitian yang tercantum pada Tabel 1 dapat dilihat bahwa pada empat rumah yang diperiksa masing- masing terdapat beberapa controllable container dan disposable container yang jumlahnya bervariasi. Dari empat rumah tersebut yang paling banyak ditemukan 
controllable container ialah rumah kedua; hal ini mungkin karena pemilik rumah ingin menggunakan banyak tempat penampungan air cadangan untuk kegiatan sehari-hari terutama untuk mencuci pakaian dan peralatan makan. Hal ini dilihat dari banyak tempat penampungan air yang dibiarkan di belakang rumah yang sering digunakan pemilik rumah untuk mencuci pakaian dan peralatan makan. Jika dilihat dari controllable container yang positif jentik, yang paling banyak ditemukan ialah pada rumah ketiga. Hal ini diduga karena pemilik rumah memiliki kesadaran yang rendah tentang kebersihan rumah terutama untuk tempat-tempat penampungan air, sehingga jika dilihat dari kondisi dapur dan kamar mandi terlihat kotor dan tempat penampungan air terdapat jentik bahkan dalam jumlah yang banyak, namun pada hasil perhitungan yang didapat, skor BRI terendah pada rumah ketiga.

Pada Tabel 2 dicantumkan disposable container yang ditemukan di tiap rumah dan hasil perhitungan HRI. Dari keempat rumah yang diperiksa, dapat dilihat rumah pertama memiliki jumlah disposable container terbanyak. Untuk disposable container yang positif jentik, rumah kedua yang terbanyak; hal ini dimungkinkan juga oleh faktor kesadaran pemilik rumah akan kebersihan lingkungan dan juga keadaan cuaca.

Dari total 30 disposable container yang ditemukan di empat rumah, terdapat lima kontainer yang positif jentik. Dari segi peluang dan jumlah disposable container yang didapat, hal ini sedikit berbeda dengan penelitian yang dilakukan oleh Dhewantara dan Dinata, ${ }^{8}$ yang memeriksa rumah yang lebih banyak (100 rumah) tetapi hanya mendapatkan total 65 disposable container dan dua kontainer yang positif jentik. Hal ini dimungkinkan karena kondisi cuaca pada penelitian Dhewantara dan Dinata sedang dalam keadaan cerah atau curah hujan yang relatif rendah dan juga kesadaran masyarakat akan kebersihan lingkungan lebih tinggi sehingga banyak sampah yang sudah dibersihkan atau dibuang dan pada akhirnya pada penelitian tersebut lebih sedikit disposable container yang ditemukan dari 100 rumah yang diperiksa.

Pada Tabel 3 dicantumkan hasil pengelompokkan tiap rumah pada kategori rendah-tinggi untuk hasil BRI, HRI, dan Indeks Maya. Dari empat rumah yang diperiksa dapat dilihat bahwa dua rumah masuk pada kategori Indeks Maya rendah, satu rumah masuk pada kategori sedang, dan satu rumah masuk pada kategori tinggi.

Walaupun rumah yang diperiksa ialah rumah yang memiliki anggota keluarga yang pernah menderita DBD namun pada penelitian ini terdapat dua rumah penderita yang masuk di kategori Indeks Maya rendah. Hal ini dapat diartikan walaupun Indeks Maya suatu rumah tergolong rendah, namun pemilik rumah tersebut tetap memiliki kemungkinan terjangkit DBD walaupun hanya kecil. Dalam hal ini juga Indeks Maya bukanlah satu-satunya faktor risiko apalagi penyebab seseorang terjangkit DBD, karena pemilik rumah yang pernah menderita DBD bisa juga terserang DBD karena terkena gigitan nyamuk Aedes aegypti bukan di rumahnya sendiri tetapi di tempat lain.

Dalam menilai risiko DBD suatu lingkungan terdapat juga beberapa cara antara lain dengan melakukan survei entomologi dengan indikator house index (HI), container index (CI), dan breteau index (BI) seperti penelitian yang dilakukan oleh Peristiowati, Lingga, dan Hariyono. ${ }^{9}$ Survei tersebut telah disesuaikan dengan standar WHO. ${ }^{10}$ Terdapat juga studi lain yaitu dengan memperoleh Angka Bebas Jentik (ABJ) yang sesuai dengan standar nasional. ${ }^{10}$ Indikator container index (CI) memiliki tujuan yang sama dengan Indeks Maya yaitu menghitung jumlah kontainer dengan kontainer yang positif jentik namun terdapat sedikit perbedaan dari proses perhitungannya karena pada Indeks Maya hal ini dilakukan lebih spesifik yaitu indikator kontainer pada Indeks Maya dibedakan menjadi dua jenis sesuai dengan kondisinya yaitu controllable container (CC) dan disposable container (DC). Controllable container adalah kontainer 
yang dalam kondisi masih digunakan, dan disposable container adalah kontainer yang sudah tidak digunakan, sedangkan pada container index (CI) kontainer-kontainer yang dihitung tidak dibedakan secara spesifik sesuai kondisinya.

\section{SIMPULAN DAN SARAN}

Berdasarkan penelitian yang telah dilakukan terhadap empat rumah penderita demam berdarah dengue di Kelurahan Kombos Barat Kecamatan Singkil dapat disimpulkan bahwa terdapat dua rumah yang masuk dalam kategori Indeks Maya rendah, satu rumah yang masuk di kategori Indeks Maya sedang, dan satu rumah yang masuk kategori Indeks Maya Tinggi.

Bagi yang akan melakukan penelitian selanjutnya, diharapkan dapat dilakukan saat kondisi curah hujan berada pada tingkat sedang sampai tinggi dan kondisi controllable container yang belum dibersihkan agar lebih banyak ditemukan aktivitas perkembangbiakan nyamuk.

Selain itu pembagian kuisioner juga perlu dilakukan untuk mengetahui pengetahuan masyarakat tentang penyakit demam berdarah dengue dan juga perilaku masyarakat terkait kebersihan lingkungan rumah.

\section{UCAPAN TERIMA KASIH}

Ucapan terima kasih disampaikan kepada semua pihak yang baik secara langsung maupun tidak langsung telah menumbuhkan ide atau gagasan dalam pemikiran penulis.

\section{DAFTAR PUSTAKA}

1. Sutanto I, Ismid IS. Buku Ajar Parasitologi Kedokteran. Jakarta: FKUI, 2008; p. 265-7.

2. Natadisastra D, Agoes R. Parasitologi
Kedokteran: Ditinjau dari Organ Tubuh yang Diserang. Jakarta: EGC, 2009; p. 315-7.

3. Kementerian Kesehatan Republik Indonesia 2015. Data dan Informasi Tahun 2014 (Profil Kesehatan Indonesia). 2015 [cited 2015 Oct 10].

4. Kewo I, Rambert G, Manoppo F. Karakteristik Eritrosit Pada Pasien Anak dengan Infeksi Virus Dengue di Manado, eBm. 2015;3(2):567.

5. Data Jumlah Penderita Penyakit DBD tahun 2015 di Kecamatan Singkil, Kota Manado, Provinsi Sulawesi Utara. Puskesmas Kombos Timur, 2015.

6. Badan Pusat Statistik Kota Manado 2015. Statistik Daerah Kecamatan Singkil Tahun 2015, 2015. Available from: http://manadokota.bps.go.id

7. Sunaryo, Pramestuti N. Surveilans Aedes aegypti di Daerah Endemis Demam Berdarah Dengue. 2014 [cited 2015 Oct 14]. Available from: http://jurnalkesmas.ui.ac.id/index.php /kesmas/article/download/415/412

8. Dhewantara PW, Dinata A. Analisis Risiko Dengue Berbasis Maya Index Pada Rumah Penderita DBD di Kota Banjar Tahun 2012. 2015 [cited 2015 Oct 27]. Available From: http://ejournal.litbang.depkes.go.id/in dex.php/jek/article/view/3844/3694

9. Peristiowati $Y$, Lingga, Hariyono. Evaluasi Pemberantasan Demam Berdarah Dengue dengan Metode Spasial Geographic Information System (GIS) dan Identifikasi Tipe Virus Dengue di Kota Kediri. 2014 [cited 2016 Jan 26]. Available From: http://jkb.ub.ac.id

10.Joharina AS, Widiarti. Kepadatan Larva Nyamuk Vektor Sebagai Indikator Penularan Demam Berdarah Dengue di Daerah Endemis Jawa Timur. 2014 [cited 2016 Jan 26]. Available from: http://ejournal.litbang.depkes.go.id. 